\title{
Lightweight masonry block without Portland cement
}

\author{
Bloco de alvenaria leve sem cimento Portland
}

Paki Turgut $^{* *} \odot$, Mehmet Can Alas ${ }^{2} \odot$, Muhammed Arif Gurel ${ }^{2} \odot$

口-

\begin{abstract}
Huge amounts of fly ash - a substance that does not conform to the ASTM C618 classification due to its chemical properties - have been abandoned in landfills around the world, despite their self-cementing property. It has not been used in concrete making applications due to its large amounts of free lime and sulfate contents. The fly ash in these plants is dumped in landfills, causing serious environmental hazards. Fly ash is disposed to the landfills by belt conveyors after being humidified with water. Therefore, the fly ashes humidified in the landfill areas are hydrated in nature. This hydration is further intensified in landfills by rain and snow. Thus, the free lime content of fly ash decreases due to its long hydration process. In this work, the lightweight masonry blocks were produced by mixing normal and hydrated fly ashes or normal, hydrated fly ash and lime without Portland cement. The compressive strength, water absorption, sorptivity, density, porosity, and thermal conductivity values of the samples produced were determined. The results obtained from these tests showed that lightweight masonry blocks could be produced by using these waste materials in building applications.
\end{abstract}

Keywords: fly ash; disposed fly ash; lime; lightweight masonry block.

\begin{abstract}
RESUMO
Enormes quantidades de cinzas volantes - uma substância que não está de acordo com a classificação ASTM C618 devido às suas propriedades químicas - foram abandonadas em aterros sanitários ao redor do mundo, apesar de sua propriedade de autocimentação. Essas substâncias não têm sido usadas em aplicações de fabricação de concreto devido às suas grandes quantidades de cal livre e teores de sulfato. A cinza volante dessas usinas é despejada em aterros sanitários, causando sérios riscos ambientais. Essas cinzas são descartadas em aterros por correias transportadoras após serem umedecidas com água. Portanto, as cinzas volantes umedecidas nas áreas do aterro são hidratadas na natureza. Essa hidratação é ainda mais intensificada em aterros, pela chuva e pela neve. Assim, o teor de cal livre nas cinzas volantes diminui devido ao longo processo de hidratação. Neste trabalho, blocos de alvenaria leves foram produzidos pela mistura de cinzas volantes normais e hidratadas, ou cinza volante normal hidratada e cal sem cimento Portland. Foram determinados os valores de resistência à compressão, absorção de água, sensibilidade, densidade, porosidade e condutividade térmica das amostras produzidas. Os resultados obtidos nesses testes mostraram que blocos de alvenaria leves podem ser produzidos usando esses materiais residuais em aplicações de construção.
\end{abstract}

Palavras-chave: cinza volante; cinza volante descartada; cal; bloco leve de alvenaria.

$\square$

\section{INTRODUCTION}

Electricity demand has increased in recent years due to the increase in the worldwide population and industrialization. A large part of the electrical energy generated in the world is obtained from the burning of coal in thermal power plants (GUPTA, et al., 2020). Depending on the type of coal burned at the plant, different classes of fly ash (FA) are obtained as waste material. While FA with high $\mathrm{SiO}_{2}(\mathrm{~S})$ amounts shows pozzolanic property, FA with $\mathrm{CaO}(\mathrm{C})$ higher than $S$ amounts exhibit both pozzolanic and cementing properties. FA with pozzolanic properties effectively converts the calcium hydroxide $(\mathrm{CH})$ formed by the hydration of Portland cement (PC) to the calcium silicate hydrate $(\mathrm{C}-\mathrm{S}-\mathrm{H})$, thereby increasing both the strength and durability of the concrete.

On the other hand, FA with both the pozzolanic and cementing properties is being used effectively in the concrete industry.

Some types of FA cannot be used in the concrete industry due to two reasons. One of them is that the chemical compositions of these FA are detrimental to the durability of the PC paste and the concrete. The other reason is that the amount of FA produced in cities where thermal power plants are located is much greater than the consumption amount in the concrete industry in these cities. In this case, if this FA is sent to other cities for use in the concrete industry, the transportation costs of the FA increases the cost of the concrete produced. However, the most important of these two reasons is the rejection of FA due to its chemical composition.

IInonu University - Malatya, Turkey.

${ }^{2}$ Harran University - Sanliurfa, Turkey.

*Corresponding author: paki.turgut@inonu.edu.tr

Conflicts of interest: the authors declare no conflicts of interest.

Funding: this work was supported by Harran University Project Centre (HUBAK), project number: 16198

Received: 11/28/2018 - Accepted: 10/13/2O2O - Reg. ABES: 20180211 
Cheerarot and Jaturapitakkul (2004) reported that the landfills of disposed FA remained a problem for all thermal power plants, as FA was not used in any production. They investigated the effect of disposed FA on physical and chemical properties of concrete. The particle sizes of disposed FA in landfill were between 55.4 and $99.3 \mu \mathrm{m}$. Its particle sizes were decreased to about 7.1$8.4 \mu \mathrm{m}$ by grinding. They found that the ground disposed FA was an excellent pozzolanic material for concrete.

The FA used in this study is not used in the concrete industry because the amount of $\mathrm{SO}_{3}(\bar{S})$ was high, which causes various problems in fresh concrete. The high free $\mathrm{C}$ amount also results in issues with the soundness of the hardened concrete at the later stages. Due to these problems, FA humidified with water (water/FA ratio: $1 / 3$ by weight) has been sent to landfills by belt conveyors, as shown in Figure 1. This FA has caused serious environmental and health hazards. The FA in these landfill areas is hydrated in nature because it has been humidified in the plant before conveying. The hydration process of FA in the landfill areas is further continued by rain and snow. Thus, the free lime content of FA has decreased due to its long hydration history. The conveying and landfilling of FA have incurred additional expenses for power plants. The most important problem is the location of new landfills in this region. Therefore, it is necessary to consume hydrated FA in old landfills.

The production of conventional brick requires the burning of a wet clay and sand mixture in the kilns (MURMU \& PATEL, 2018). The use of clay, cement or sand in the production of different kinds of bricks as building material has given rise to exhausting natural resources, thus gradually degrading the environment in the long run due to high burning temperature, high energy use, and high emission of carbon dioxide $\left(\mathrm{CO}_{2}\right)$. Hence, the use of industrial by-products as alternative materials and binder for the fabrication of bricks has been found to be significant in overcoming this problem (PAHRORAJI et al., 2020).

The environmental issues faced in today's world have forced building industries to develop more environmentally friendly construction materials. The use of FA in the masonry wall block production may contribute to the sustainability of the production of building materials. Using industrial waste produces more efficient building materials and, correspondingly, reduces the use of natural resources. Thus, it contributes to the development of construction engineering (McLELLAN et al., 2011).

In the literature, masonry blocks were produced by using lime-FA mixtures (CICEK \& TANRIVERDI, 2007; TOKYAY \& CETIN, 1991; KUMAR, 2002; CHINDAPRASIRT \& PIMRAKSA, 2008). Blocks were also produced with clay-FA mixtures (GARCIA-UBAQUE et al., 2007; LINGLING et al., 2005; CHOU, 2001). Turgut (2010; 2012; 2013) produced composite materials without PC by using class C FA-limestone powder, class C FA-limestone powder-silica fume, or class C FA-limestone powder-glass powder. The test results obtained from these works provided the national and the international standards related to masonry building blocks. Detailed literature reviews related to the production of bricks from waste materials were given by Zhang (2013) and Murmu and Patel (2018).

In this study, lightweight masonry blocks with normal and hydrated FA were simply produced. Their compressive strength, unit weight, water absorption, sorptivity, thermal conductivity, and porosity values were determined.

\section{METHODOLOGY}

\section{Properties of used materials}

The normal fly ash (NFA) and the hydrated fly ash (HFA) from Kangal Power Plant were used as the main materials in the production of samples. HFA was collected from the landfill in the summer season. After weighing a small amount of HFA, $500 \mathrm{~g}$, it was dried in an oven at $110^{\circ} \mathrm{C}$ for 24 hours. The dried HFA was re-weighed and its weight remained unchanged. This showed that HFA did not contain evaporable water. In the cement industry, the test of loss on ignition (LOI) is routinely used to determine the amount of residual carbon and the presence of carbonates and combined water (BILODEAU et al., 1994). As seen in Table 1, LOI values of NFA and HFA were 2.42 and $19.80 \%$, respectively. The fact that the LOI value of HFA was larger than that of NFA showed that HFA had combined water in its hydration products.
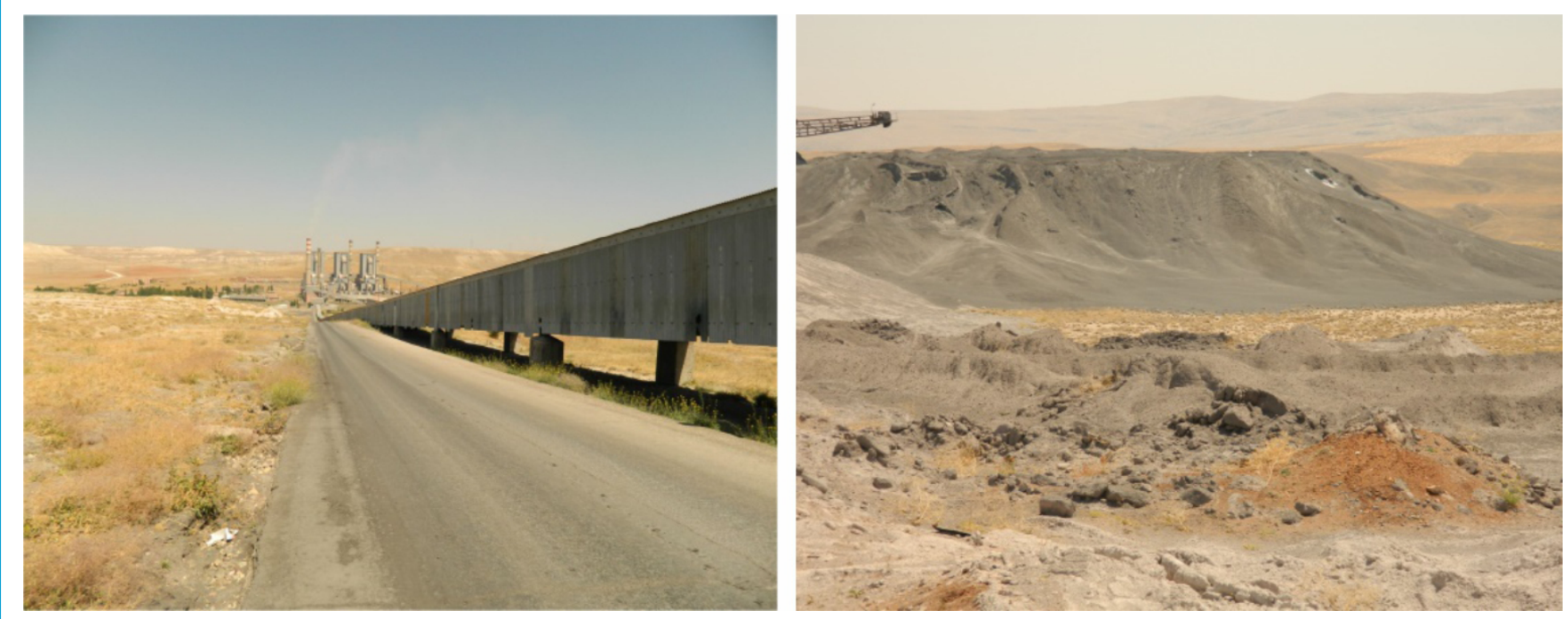

Source: elaboratedy by the authors

Figure 1 - Hydrated fly ash in landfill area. 
Table 1 - Chemical compositions and physical properties of materials used.

\begin{tabular}{l|c|c|c}
\hline Chemical composition (\%) & NFA & HFA & L \\
$\mathrm{CaO}$ & 32.58 & 28.77 & 70.08 \\
\hline $\mathrm{SiO}_{2}$ & 26.79 & 21.21 & 0.87 \\
\hline $\mathrm{Al}_{2} \mathrm{O}_{3}$ & 12.01 & 8.78 & 0.20 \\
\hline $\mathrm{Fe}_{2} \mathrm{O}_{3}$ & 5.67 & 5.01 & 0.14 \\
\hline $\mathrm{Na}_{2} \mathrm{O}$ & 1.56 & 1.17 & 0.49 \\
\hline $\mathrm{K}_{2} \mathrm{O}$ & 0.75 & 0.60 & - \\
\hline $\mathrm{MgO}$ & 4.34 & 3.57 & 1.34 \\
\hline $\mathrm{SO}$ & 12.06 & 9.67 & 0.96 \\
\hline $\mathrm{Cl}$ & 0.03 & 0.013 & 0.02 \\
\hline Free CaO & 3.46 & 0.48 & - \\
\hline LOI & 2.42 & 19.80 & 25.74 \\
\hline Density & 2.35 & 2.33 & 2.25 \\
\hline Specific surface area (cm²/g) & 2.047 & 2.437 & 5.831 \\
\hline
\end{tabular}

NFA: normal fly ash; HFA: hydrated fly ash; L: lime; LOI: Ioss on ignition. Source: elaboratedy by the authors.

Lime (L) was used to improve some properties of the samples, such as workability, unit weight, water absorption, sorptivity, and compressive strength.

The chemical compositions of the powder materials were determined by XRF method. Samples of powder materials were prepared as a pellet of pressed powder. A cylindrical sample die and a hydraulic machine were used to obtain a pellet. The die was filled with powdered material, which was then compressed by the hydraulic machine to form the pellet. The prepared pellet was analyzed in the XRF device (DIN, 2007).

The fineness of materials was determined by using Blaine's air-permeability apparatus (ASTM, 2018). The specific surfaces were expressed as total surface area in square centimetres per gram. The densities of materials were determined by following the standard test method used for testing hydraulic cement (ASTM, 2017). The standard Le Chatelier flask with circular cross section was used in this test method.

The chemical and physical properties of the NFA, HFA, and L were given in Table 1. As displayed in Table 1, NFA had cementing properties due to the high contents of $C$ and $\bar{S}$ (TURGUT, 2010; 2012; 2013). The high composition of $\bar{S}$ caused some problems in hardened concrete. In PC concrete, $\bar{S}$ reacted with $\mathrm{CH}$, resulting in a weakening action that leads to cracking of the cement paste, affecting its durability due to excessive ettringite formation (MOHAMMED et al., 2004). The high amount of free $C$ also led to some soundness problems in the hardened concrete at later stages, as it gave rise to expansion during the hydration reaction while free $\mathrm{C}$ was converted to $\mathrm{CH}$ (HUSILLOS RODRIGUEZ et al., 2013).

HFA had aproximately similar chemical compositions to NFA, though it was in the hydrated state. Hence, it did not possess cementing properties and behaved as an inert material in the samples. After prolonged hydration in the landfill, the free $\mathrm{C}$ amount decreased from 3.46 to $0.48 \%$. HFA was taken from different regions at the landfill. HFA was milled, and then sieved through a $150 \mu \mathrm{m}$ mesh. The grinding process was quite easy and fast due to the loose agglomerated nature of the HFA. The specific surface area of HFA was $2,437 \mathrm{~cm}^{2} / \mathrm{g}$ after grinding.
The $\mathrm{L}$ used in this work was hydrated lime in the form of a commercial product. The NFA and HFA are shown in Figure 2. The colours of HFA and NFA were light gray and gray, respectively. The Scanning Electrone Microscopy (SEM) micrographs of the NFA, HFA, and L are also given in Figure 2. As shown in Figure 2, the HFA had some hydration products like the $\mathrm{C}-\mathrm{S}-\mathrm{H}$ and $\mathrm{CH}$.

\section{Preparation of samples}

In this study, three groups of samples were produced, namely $\mathrm{N}, \mathrm{NH}$, and NHL. One group $(\mathrm{N})$ was the control sample containing only NFA. The second group (NH) contained NFA and HFA while the last group (NHL) consisted of NFA, HFA, and L. In the NH group, NFA was replaced by HFA in the various levels by weight. In the NHL group, $\mathrm{L}$ was taken as a constant amount while NFA was replaced by HFA in the different levels by weight. The samples and the quantities of their mixtures were given in Table 2. For example, the $7 \mathrm{~N} 1 \mathrm{H}$ sample showed that the HFA/NFA ratio was $1 / 7$ by weight. In the $32 \mathrm{~N} 5 \mathrm{H} 3 \mathrm{~L}$ sample, the L/HFA/NFA ratios were the $3 / 5 / 32$ by weight. The amount of water (W) was constant in all samples. The W/(NFA+HFA) or W/(NFA+HFA+L) ratio was taken as 0.38 in all mixtures to determine the effects of various NFA and HFA or NFA, HFA, and L combinations. The High Range Water Reducer (HRWR) was used in mixtures, and its amount was $1 \%$ of the NFA+HFA or $\mathrm{NFA}+\mathrm{HFA}+\mathrm{L}$ weight. HRWR admixture was used to reduce the amount of water in the blend. It was used to increase the consistency and workability of mixtures (ASTM, 2017). The density and pH values of HRWR were 1.092 and $7.03 \mathrm{gr} / \mathrm{cm}^{3}$.

The production scheme of samples is shown in Figure 3. In the mixing process, the NFA-HFA or NFA-HFA-L was mixed in a concrete mixer in the dry form for one minute (Figure 4a). Following this, the water and HRWR were added to the mixture and mixed for an additional nine minutes. Subsequently, the fresh mixtures in plastic consistency or in wet states were fed into the moulds with dimensions of $50 \mathrm{~mm}$ cube and $\phi 45 \times 90 \mathrm{~mm}$ cylinder while the shaking table was working (Figure $4 \mathrm{~b}$ ). The mixtures in the moulds were compacted by shaking the table for one minute. After shaking, all fresh mixtures were observed to be in the flowable consistency in the moulds. The NHL mixtures reached flowable consistency earlier than the $\mathrm{N}$ and $\mathrm{NH}$ mixtures. The reason being that the $\mathrm{Ca}^{2+}$ ions were the determining ions on the electrically charged surfaces (VIALLIS-TERRISSE et al., 2001). The adsorption of $\mathrm{Ca}^{2+}$ onto lime particles justifies the large positive value of zeta potential in the $\mathrm{Ca}^{2+}$ - rich lime suspension.

The open surfaces of moulds were finished and covered with plastic wrap (Figure 4c-d). A container with filled water was placed in the oven in order to moisten the inside of the oven. All samples were cured in the oven at $70^{\circ} \mathrm{C}$ for 24 hours for early strength development (Figure 4e). The oven was turned off after 24 hours. The samples were instinctively cooled to room temperature in the oven. Subsequently, the samples were removed from the moulds. The other samples were cured for periods of 7, 28, and 56 days in the curing tank filled with water at $23^{\circ} \mathrm{C}$, while some samples cured for one day were used to test the compressive strength. Three samples were used for each test and their mean values were calculated.

\section{Test methods for produced samples}

Unit weight, water absorption, and sorptivity tests were performed on the $\phi 45 \times 90 \mathrm{~mm}$ cylinder samples by following the American Society for Testing 


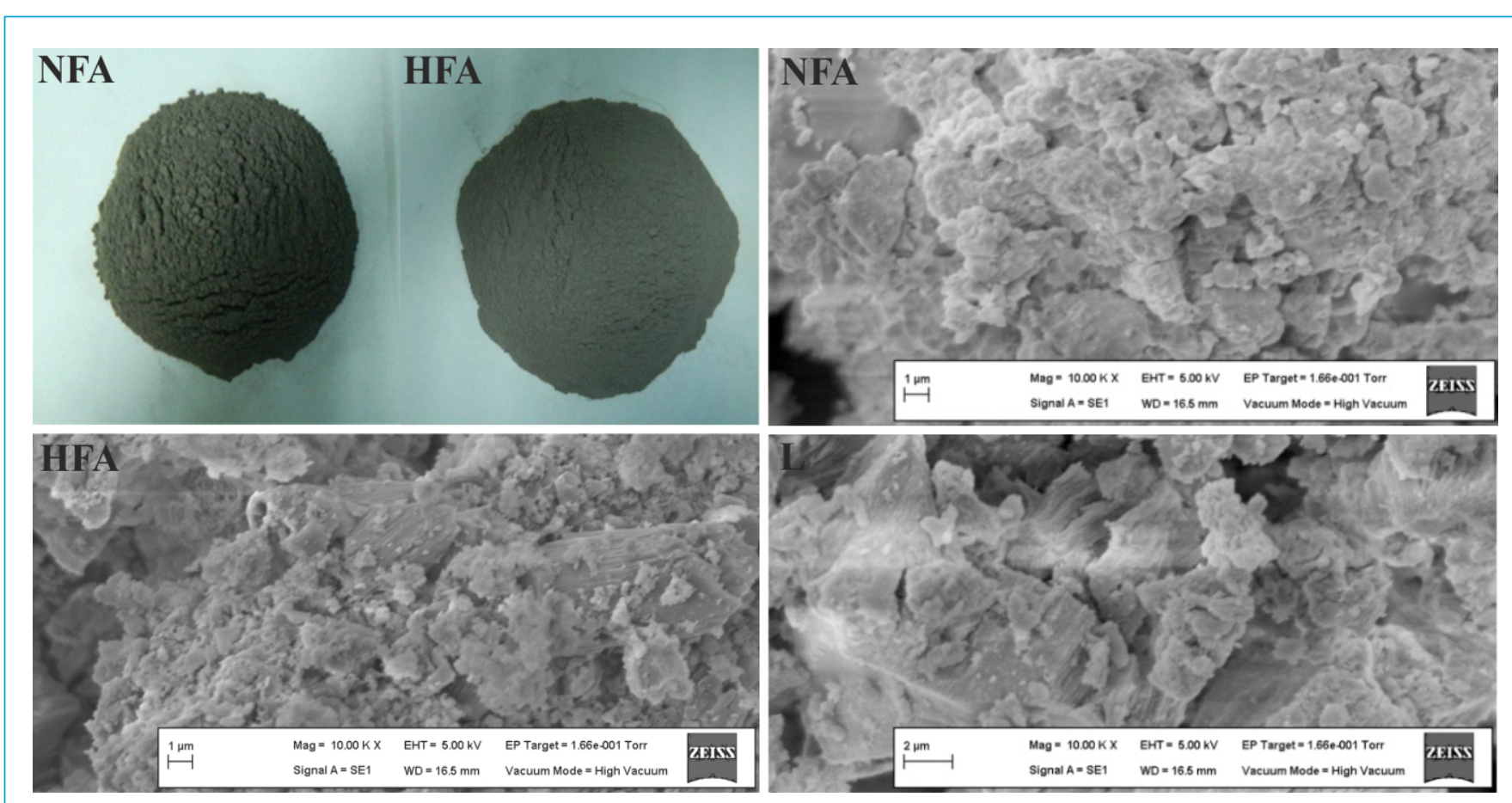

NFA: normal fly ash; HFA: hydrated fly ash; EHT: electron high tension; WD: working distance; Mag: magnification; Signal A = SE1: secondary electron; EP Target: vacuum pressure. Source: elaboratedy by the authors.

Figure 2 - Normal fly ash and hydrated fly ash and scanning electrone microscopy micrographs of materials used.

Table 2 - Mixture amounts $\left(\mathrm{kg} / \mathrm{m}^{3}\right)$.

\begin{tabular}{l|c|c|c|c|c}
\hline Numune adI & NFA & L & HFA & W & HRWR \\
\hline $\mathrm{N}$ & 1,130 & - & - & 429 & 11.30 \\
\hline $7 \mathrm{N1H}$ & 989 & - & 141 & 429 & 11.30 \\
\hline $3 \mathrm{~N} 1 \mathrm{H}$ & 848 & - & 283 & 429 & 11.30 \\
\hline $5 \mathrm{~N} 3 \mathrm{H}$ & 706 & - & 424 & 429 & 11.30 \\
\hline $1 \mathrm{N1H}$ & 565 & - & 565 & 429 & 11.30 \\
\hline $32 \mathrm{~N} 5 \mathrm{H} 3 \mathrm{~L}$ & 904 & 85 & 141 & 429 & 11.30 \\
\hline $27 \mathrm{N1OH} 3 \mathrm{~L}$ & 763 & 85 & 283 & 429 & 11.30 \\
\hline $22 \mathrm{~N} 15 \mathrm{H} 3 \mathrm{~L}$ & 621 & 85 & 424 & 429 & 11.30 \\
\hline $17 \mathrm{~N} 2 \mathrm{OH} 3 \mathrm{~L}$ & 480 & 85 & 565 & 429 & 11.30 \\
\hline
\end{tabular}

NFA: normal fly ash; HFA: hydrated fly ash; L: lime; N: one group; W: water; HRWR: High Range Water Reducer. Source: elaboratedy by the authors.

and Materials (ASTM, 2006) and the Europe Norm (EN, 2011). All samples were dried in an oven at $110^{\circ} \mathrm{C}$ for 24 hours. The samples were then slowly cooled to the room temperature in the oven. All samples were weighed, and their unit weight values were computed by the following relationship.

$\mathrm{d}=\mathrm{G} / \mathrm{V}$

Where, $\mathrm{d}, \mathrm{G}$, and $\mathrm{V}$ were the unit weight $\left(\mathrm{kg} / \mathrm{m}^{3}\right)$, the oven-dry weight $(\mathrm{kg})$, and the volume $\left(\mathrm{m}^{3}\right)$ of the samples, respectively.

In the sorptivity test, the side surfaces of $\phi 45 \times 90 \mathrm{~mm}$ cylinder samples were covered by the plastic sealing material to prevent water evaporation in the

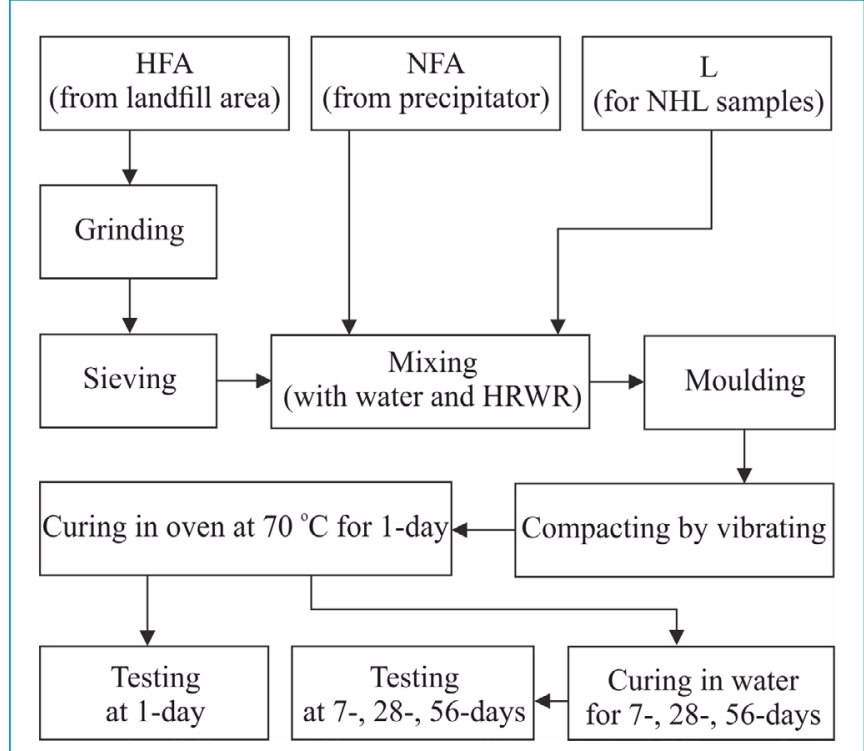

NFA: normal fly ash; HFA: hydrated fly ash; L: lime; HRWR: High Range Water Reducer. Source: elaboratedy by the authors.

Figure 3 - Production schema of samples.

testing stage. The samples were immersed in water at about $5 \mathrm{~mm}$ from their bottom level. Weight increases in the samples were recorded in 5, 10, 60, 240, and 1,440 min. Sorptivity values were calculated by using weight differences and determined by the following relationship.

$\mathrm{Q} / \mathrm{A}=\mathrm{kt}^{-0.5}$ 


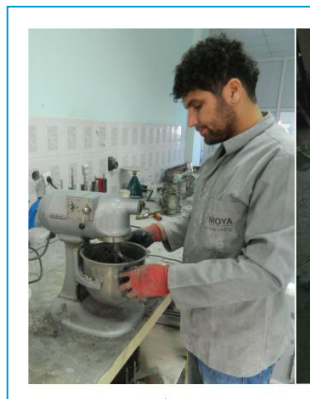

a)

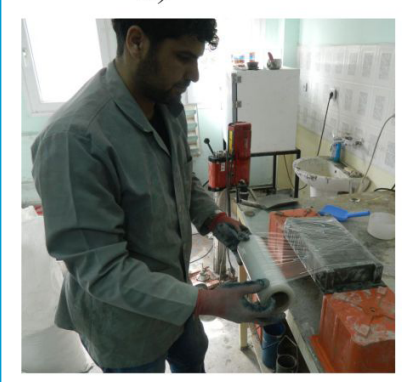

d)

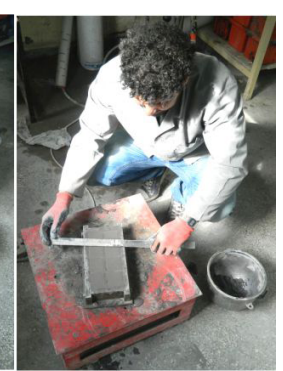

c)

b)

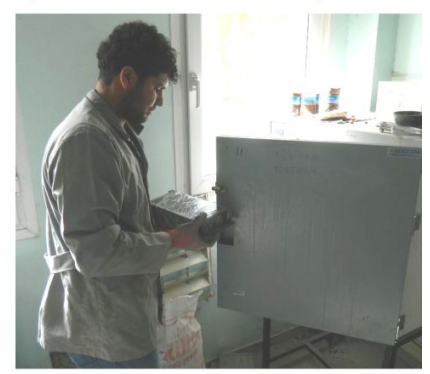

e)
Source: elaboratedy by the authors.

Figure 4 - Production of samples.

Where, $k, \mathrm{~A}, \mathrm{t}$, Q were the sorptivity value $\left(\mathrm{cm} . \mathrm{s}^{-0.5}\right)$, the surface area to be exposed to water $\left(\mathrm{cm}^{2}\right)$, the time $(\mathrm{s})$, and absorbed water $\left(\mathrm{cm}^{3}\right)$ for the sample, respectively.

In the water absorption tests, the samples dried in the oven were immersed in water at $21^{\circ} \mathrm{C}$ for 48 hours. Subsequently, the water absorbed weights of the samples were measured. The water absorption amounts as weight percent were calculated using the following relationship.

$\mathrm{S}_{\mathrm{w}}=100(\mathrm{~B}-\mathrm{G}) / \mathrm{G}$

Where, $S_{w}, B$, and $G$ were the water absorption (\%) by weight, the saturated surface dry weight $(\mathrm{kg})$, and the oven dry weight $(\mathrm{kg})$ of the samples.

The volumetric water absorption $\left(\mathrm{S}_{\mathrm{v}}\right)$ of the samples was determined by the following relationship.

$\mathrm{S}_{\mathrm{v}}=\mathrm{S}_{\mathrm{w}} \times \mathrm{d}$

Where, $d$ was the unit weight of samples $\left(\mathrm{kg} / \mathrm{m}^{3}\right)$.

To find the densities of the samples, the sample was grinded and sieved with a $0.075 \mathrm{~mm}$ mesh. The weight of the powdered $\left(\mathrm{P}_{\mathrm{o}}\right)$ sample was determined. Then, this powder sample was poured into the pycnometer-filled liquid. Thus, the volume of the powder $\left(\mathrm{V}_{\mathrm{d}}\right)$ sample was measured. The density of the sample was constituted using the following relationship. Here, $\mathrm{P}_{\mathrm{o}}$ was the weight of the powder.

$\mathrm{D}=\mathrm{P}_{\mathrm{o}} / \mathrm{V}_{\mathrm{d}}$
The apparent volume (V) was determined by measuring the $\phi 45 \times 90 \mathrm{~mm}$ cylinder sample. The apparent volume was equal to the total amount of solid and the void sections.

$\mathrm{V}=\mathrm{V}_{\mathrm{d}}+\mathrm{V}_{\mathrm{b}}$

Thus, porosity was found by using the following relationship:

$\mathrm{P}=\mathrm{V}_{\mathrm{b}} / \mathrm{V}$

The thermal conductivity test of the samples ( $\phi 45 \times 90 \mathrm{~mm}$ cylinder) was measured via hot-wire method with a KEM QTM-500 Quick Thermal Conductivity Meter at room temperature based on the ASTM (2019) standard. Thermal conductivity is the transport of energy through a material due to a temperature gradient. The calculation of thermal conductivity was given by the following relationship:

$\frac{\Delta \mathrm{Q}}{\Delta \mathrm{t} \cdot \mathrm{A}}=-\mathrm{k} \frac{\Delta \mathrm{T}}{\Delta \mathrm{x}}$

In this relationship, $\mathrm{k}$ was the thermal conductivity. $\mathrm{DQ} / \mathrm{Dt}$ was the transported heat per unit of time. DT/Dx was the temperature gradient through an area. A was the cross-sectional area over which the temperature gradient was measured.

Compressive strength tests were performed on the $50 \mathrm{~mm}$ cube samples by following the ASTM (2008).

$\mathrm{f}_{\mathrm{m}}=\mathrm{P} / \mathrm{S}$

Where, $\mathrm{f}_{\mathrm{m}}$ was the compressive strength (MPa), $\mathrm{P}$ was the ultimate load $(\mathrm{N})$, and $\mathrm{S}$ was the cross-sectional area $\left(\mathrm{mm}^{2}\right)$ of the sample.

\section{RESULTS AND DISCUSSIONS}

The unit weight and porosity values of the samples at 56 days of curing were shown in Figure 5. The unit weight values of the samples decreased and the porosities of the samples increased with the increase of HFA amount in the NFA. The reason for this was not their density difference because the NFA and HFA densities were nearly identical, and their values were 2.35 and $2.33 \mathrm{gr} / \mathrm{cm}^{3}$, respectively. The reason was probably the air entraining effect of HFA. The unit weight of the $1 \mathrm{~N} 1 \mathrm{H}$ sample was only $1,303 \mathrm{~kg} / \mathrm{m}^{3}$, while $\mathrm{N}$ (control) was 1,537 $\mathrm{kg} / \mathrm{m}^{3}$. The unit weight values of the NHL samples were lower than those of $\mathrm{NH}$ due to the low density value of $\mathrm{L}\left(2.25 \mathrm{gr} / \mathrm{cm}^{3}\right)$. Moreover, the porosities of the NHL samples were also decreased when compared to the NH samples.

The water absorption and the sorptivity values of the samples after 56 days of curing are shown in Figure 6. Generally, the water absorption and sorptivity values of the samples increased with the increase of the HFA amount in the samples. In the $\mathrm{NH}$ samples, the water absorption of $7 \mathrm{~N} 1 \mathrm{H}$ sample was the same for the $\mathrm{N}$ sample while increasing as those of the other samples. The water absorption values of the NHL samples effectively decreased due to their low porosity values. According to ASTM (2002), the maximum allowable water absorption is $0.288 \mathrm{~kg} / \mathrm{m}^{3}$ for load bearing and non-load-bearing concrete masonry units. All samples satisfied this limit value except the $1 \mathrm{~N} 1 \mathrm{H}$ sample. 


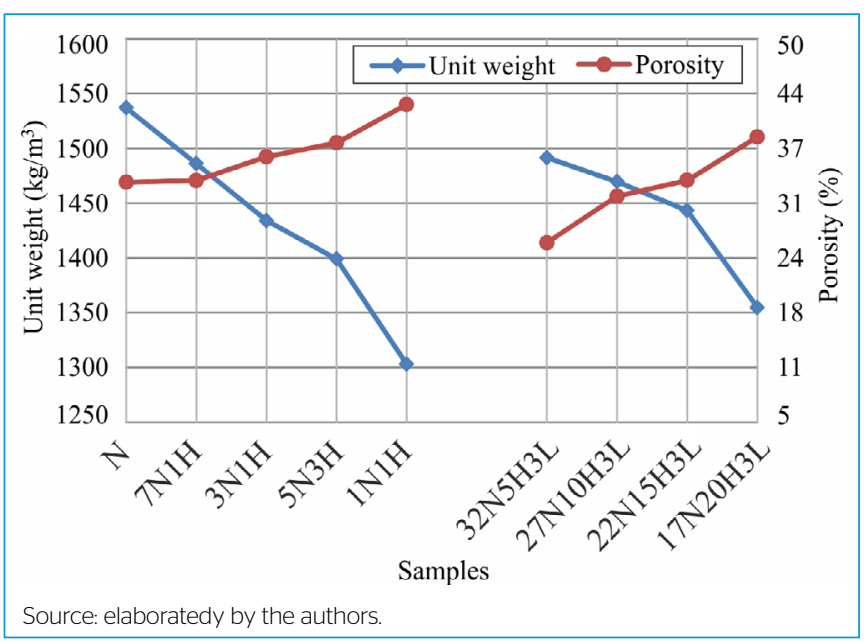

Figure 5 - Unit weight and porosity values of samples.

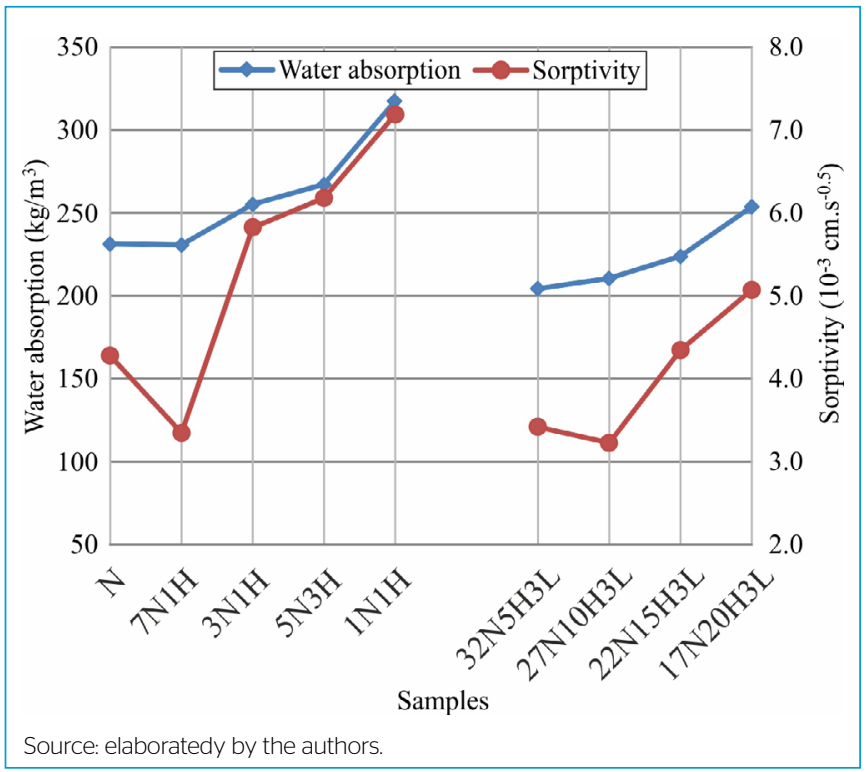

Figure 6 - Water absorption and sorptivity values of samples.

In the $\mathrm{NH}$ samples, the sorptivity values increased with the increase of the HFA amount in the samples as compared to the $\mathrm{N}$ sample except for the $7 \mathrm{~N} 1 \mathrm{H}$ sample. The sorptivity values of the NHL samples effectively decreased with $\mathrm{L}$ as compared to the $\mathrm{N}$ sample. This decrease was probably due to the blockage of fine pores by $\mathrm{L}$. The sorptivity values of some common materials were 12.12 $-13.50 \times 10^{-3} \times \mathrm{cm} / \mathrm{s}^{0.5}$ for aerated concrete and $5.41-6.47 \times 10^{-3} \times \mathrm{cm} / \mathrm{s}^{0.5}$ for pumice concrete (OZDEMIR, 2002). The sorptivity values were lower than these values in the NHL samples.

The thermal conductivity values of the samples after 56 days of curing are shown in Figure 7. Thermal conductivity is defined as a material's ability to conduct heat. The thermal conductivity values of the $\mathrm{N}, 7 \mathrm{~N} 1 \mathrm{H}, 3 \mathrm{~N} 1 \mathrm{H}, 5 \mathrm{~N} 3 \mathrm{H}$, and $1 \mathrm{~N} 1 \mathrm{H}$ samples were $0.388,0.378,0.362,0.323$, and $0.281 \mathrm{~W} / \mathrm{mK}$ while those of the $32 \mathrm{~N} 5 \mathrm{H} 3 \mathrm{~L}, 27 \mathrm{~N} 10 \mathrm{H} 3 \mathrm{~L}, 22 \mathrm{~N} 15 \mathrm{H} 3 \mathrm{~L}$, and $17 \mathrm{~N} 20 \mathrm{H} 3 \mathrm{~L}$ samples were 0.435 , $0.377,0.363$, and $0.318 \mathrm{~W} / \mathrm{mK}$, respectively. According to the CEN standardization (CEN, 2015), the thermal conductivity values of the bricks should be less than $0.450 \mathrm{~W} / \mathrm{mK}$. As seen from the test results, the thermal conductivity values

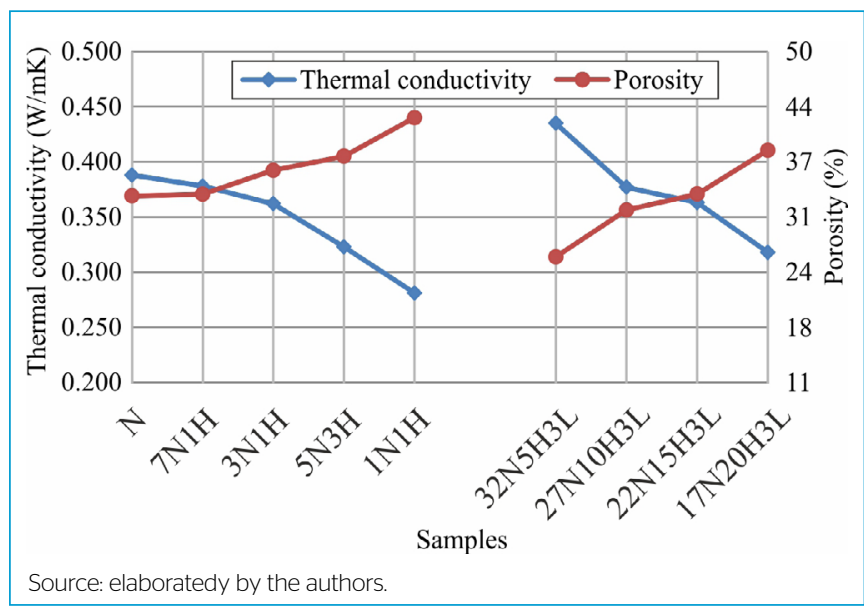

Figure 7 - Thermal conductivity values of samples.

of all samples satisfied the related standard. The thermal conductivity values of the samples decreased with the increase of the HFA amount in the samples while the porosity values of the samples increased. There was a strong relationship between the thermal conducticity and the porosity values of the samples because the air is a poor conductor for heat. The thermal conductivity values of the NH samples were lower than that of the NHL samples. L increased the thermal conductivity values in the NHL samples due to the blockage of some pores.

The major hydration products formed during the hydration of NFA with the water were given as a general knowledge in the Eq. (10-13) as follows. The $\mathrm{C}-\mathrm{S}-\mathrm{H}, \mathrm{C}-\mathrm{A}-\mathrm{H}, \mathrm{C}-\mathrm{A}-\mathrm{S}-\mathrm{H}$ and $\mathrm{C}-\mathrm{A}-\mathrm{C} \overline{\mathrm{S}}-\mathrm{H}$ showed calcium silicate hydrates, calcium aluminate hydrates, calcium aluminate silicate hydrates, and calcium aluminate calcium sulfate hydrates (ettringite), respectively.

$\mathrm{CH}+\mathrm{S}+\mathrm{H}=\mathrm{C}-\mathrm{S}-\mathrm{H}$

$\mathrm{CH}+\mathrm{A}+\mathrm{H}=\mathrm{C}-\mathrm{A}-\mathrm{H}$

$\mathrm{CH}+\mathrm{A}+\mathrm{S}+\mathrm{H}=\mathrm{C}-\mathrm{A}-\mathrm{S}-\mathrm{H}$

$\mathrm{CH}+\mathrm{A}+\overline{\mathrm{S}}+\mathrm{H}=\mathrm{C}-\mathrm{A}-\mathrm{C} \overline{\mathrm{S}}-\mathrm{H}$

Figure 8 showed the SEM micrographs of the N, NH, and NHL samples after 56 days. All samples had the $\mathrm{C}-\mathrm{S}-\mathrm{H}, \mathrm{CH}$, or ettringite. The self-hardening property of NFA in the presence of water was deduced to be due to its higher $\mathrm{C}$ content.

The compressive strength results of all samples are displayed in Figure 9 for different curing conditions. ASTM (2009) required a minimum compressive strength of $11.7 \mathrm{MPa}$ for load-bearing concrete masonry units. As seen in Figure 9, the compressive strengths of all samples cured in an oven at $70^{\circ} \mathrm{C}$ for even one day satisfied the ASTM (2009). The compressive strengths of all the samples cured in water at $23^{\circ} \mathrm{C}$ for 7,28 , and 56 days were higher than those of all the samples cured in the oven for one day at $70^{\circ} \mathrm{C}$. This showed that the amount of hydration products continously increased by water curing. The highest compressive strength occurred in the $\mathrm{N}$ sample after 56 days with a value of $46 \mathrm{MPa}$. The compressive strength of the $32 \mathrm{~N} 5 \mathrm{H} 3 \mathrm{~L}$ sample was $45.1 \mathrm{MPa}$. The increases of the compressive strength in the $\mathrm{N}, 7 \mathrm{~N} 1 \mathrm{H}, 3 \mathrm{~N} 1 \mathrm{H}, 5 \mathrm{~N} 3 \mathrm{H}$, and 

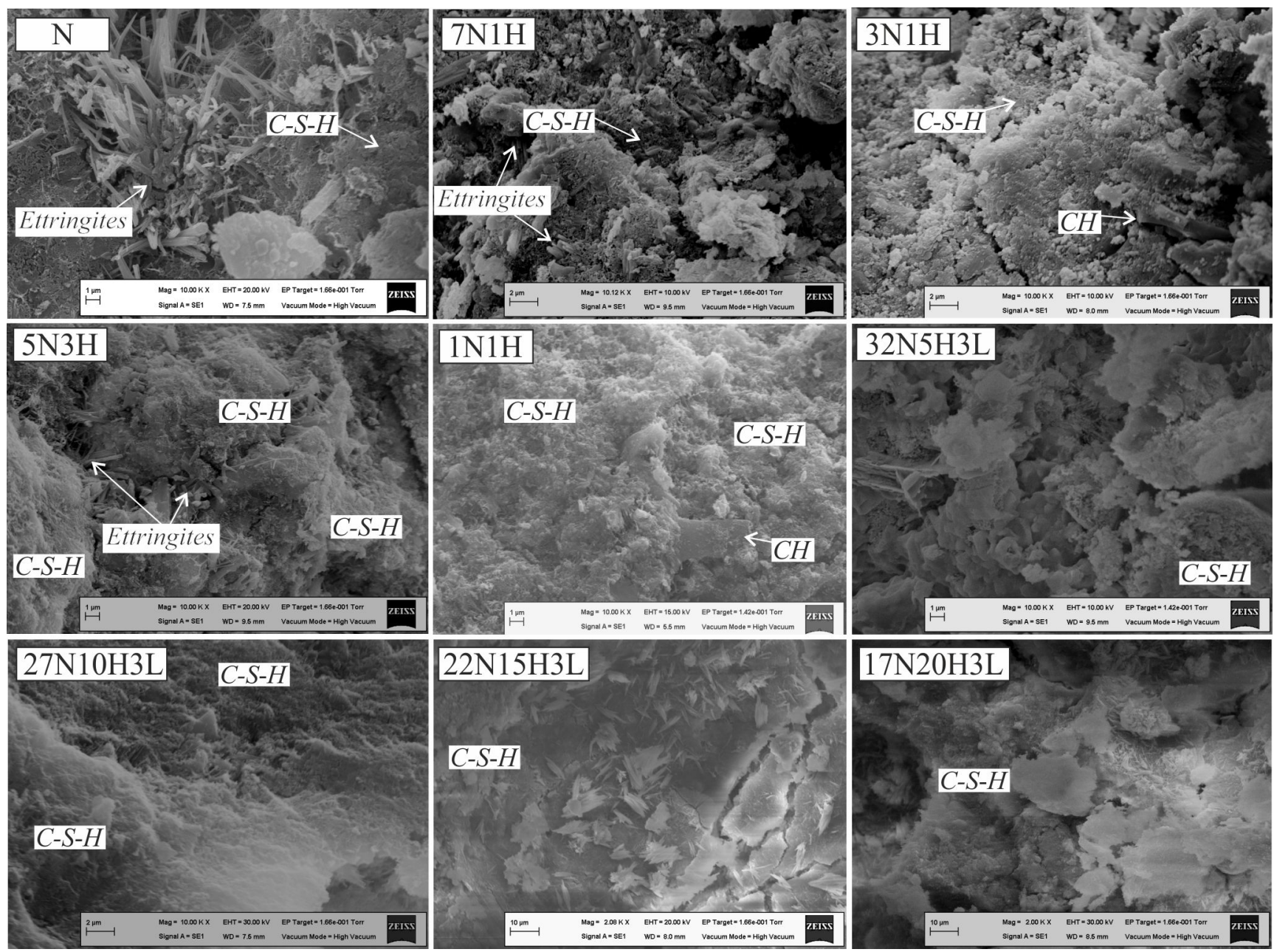

Source: elaboratedy by the authors.

Figure 8 - Scanning electrone microscopy micrographs of the one group, second group, and last group samples.

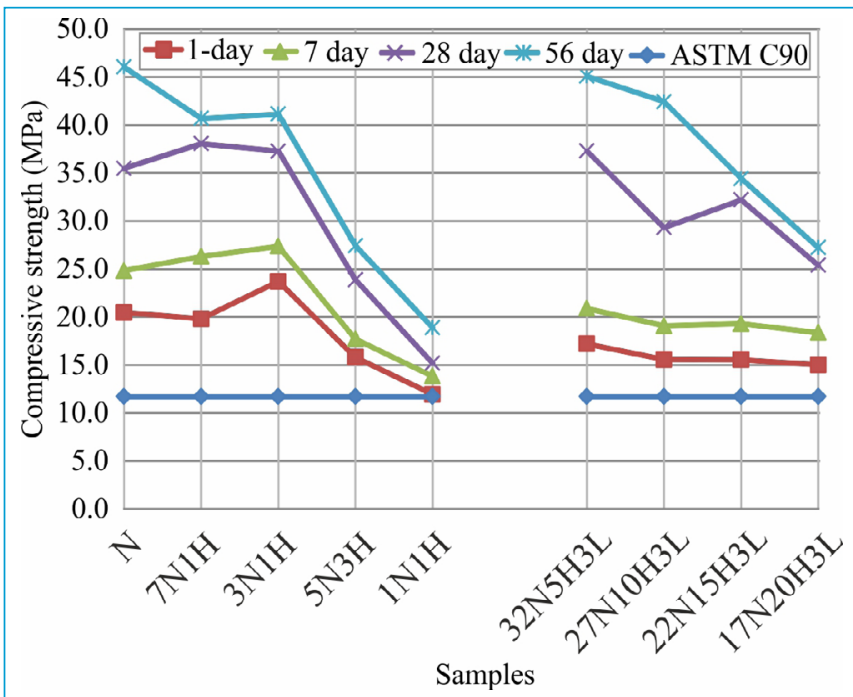

ASTMC: American Society for Testing and Materials = ASCE. Source: elaboratedy by the authors.

Figure 9 - Compressive strength values of samples.
$1 \mathrm{~N} 1 \mathrm{H}$ samples at 56 days were $120,110,70,70$, and $60 \%$ higher than the values observed for those cured in the oven for one day while the increases in the 32N5H3L, 27N10H3L, 22N15H3L, and 17N20H3L samples were 160, 170, 120, and $80 \%$ higher than the values observed for those cured in the oven for one day. The compressive strengths in the $5 \mathrm{~N} 3 \mathrm{H}$ and $1 \mathrm{~N} 1 \mathrm{H}$ samples decreased sharply as compared to the $\mathrm{N}$ samples due to the increased porosity values of these samples. Another reason for this decrease in compressive strengths was that HFA did not possess any cementing property in the samples. The beneficial effects of $\mathrm{L}$ in the NHL samples were seen in the $22 \mathrm{~N} 15 \mathrm{H} 3 \mathrm{~L}$ and $17 \mathrm{~N} 20 \mathrm{H} 3 \mathrm{~L}$ samples. Their compressive strengths effectively increased at 28 and 56 days compared to the $5 \mathrm{~N} 3 \mathrm{H}$ and $1 \mathrm{~N} 1 \mathrm{H}$ samples at the same ages. In production, there were two preferences. Low strength could be obtained in the fast production by using oven cure at $70^{\circ} \mathrm{C}$ while the high strength was acquired in the delayed production by using water cure at $23^{\circ} \mathrm{C}$ for 56 days. The $1 \mathrm{~N} 1 \mathrm{H}$ or $17 \mathrm{~N} 20 \mathrm{H} 3 \mathrm{~L}$ samples could be effectively used for consuming HFA in the landfill. The compressive strengths of the $17 \mathrm{~N} 20 \mathrm{H} 3 \mathrm{~L}$ samples were greater than those of the $1 \mathrm{~N} 1 \mathrm{H}$ samples due to the effect of $\mathrm{L}$ in the mix. As seen in Table 2, the amounts of HFA were the same in the $1 \mathrm{~N} 1 \mathrm{H}$ and $17 \mathrm{~N} 20 \mathrm{H} 3 \mathrm{~L}$ samples. The increase of compressive strength in the $17 \mathrm{~N} 20 \mathrm{H} 3 \mathrm{~L}$ sample was $30 \%$ higher than that of the $1 \mathrm{~N} 1 \mathrm{H}$ 
sample for 1 day in oven curing. The compressive strengths of the $17 \mathrm{~N} 20 \mathrm{H} 3 \mathrm{~L}$ samples were 30,70 , and $40 \%$ higher than those of the $1 \mathrm{~N} 1 \mathrm{H}$ samples for water curing at 7,28 , and 56 days, respectively.

\section{CONCLUSIONS}

The following conclusions can be formed regarding the samples produced in this study:

The FA generated at the coal-fired power plant in the region is unused and ends up in landfill areas. Using normal and HFA to make lightweight artificial stone for building applications not only produces a valuable commercial product for buildings but also combats a major waste disposal problem for the power plant.

The production of samples from mixtures of normal-hydrated FA or normal-hydrated fly ash-lime is possible using existing brick or block manufacturing plants. The production method of samples is also very simple and easy.

The results are indicative of the satisfactory performance of the samples as load-bearing elements, in terms of mechanical, some physical, and thermal properties. It is seen that the air entraining effect of hydrated FA in the mixtures increases the porosity and decreases the thermal conductivity values of samples.
Depending on the different curing methods and times, the compressive strength values of the samples ranged from 11.9 to $46 \mathrm{MPa}$. Thermal conductivity values of samples cured for 56 days varied between 0.281 and $0.435 \mathrm{~W} /$ $\mathrm{mK}$, while the unit weight values of samples ranged from 1,303 to $1,537 \mathrm{~kg} /$ $\mathrm{m}^{3}$. The lowest and highest water absorption values in the samples cured for 56 days were 204 and $318 \mathrm{~kg} / \mathrm{m}^{3}$. The sorptivity values samples cured for 56 days varied between $3.22 \times 10^{-3} \times \mathrm{cm} / \mathrm{s}^{0.5}$ and $7.19 \times 10^{-3} \times \mathrm{cm} / \mathrm{s}^{0.5}$.

The test results of the lightweight masonry block samples produced from NFA in precipators and HFA in landfill areas were the acceptable levels as physical, mechanical, and thermal properties, although their durability tests are still needed. The durability tests of the masonry block samples produced should be approached in future works.

\section{AUTHORS' CONTRIBUTIONS}

Turgut, P.: Conceptualization, Determination of mix proportions of samples, Preparation of test program of samples, writing. Alas, M.C.: Production and testing of samples, Evaluation of test results. Gurel, M.A.: Review and correcting of paper.

\section{REFERENCES}

AMERICAN SOCIETY FOR TESTING AND MATERIALS (ASTM). C 204$18 e 1$ - Standard Test Methods for Fineness of Hydraulic Cement by AirPermeability Apparatus. West Conshohocken, Pennsylvania, 2018.

AMERICAN SOCIETY FOR TESTING AND MATERIALS (ASTM). C109 Standard Test Method for Compressive Strength of Hydraulic Cement Mortars. West Conshohocken, Pennsylvania, 2008

AMERICAN SOCIETY FOR TESTING AND MATERIALS (ASTM). C1113M-O9 - Standard Test Method for Thermal Conductivity of Refractories by Hot Wire (Platinum Resistance Thermometer Technique). West Conshohocken, Pennsylvania, 2019

AMERICAN SOCIETY FOR TESTING AND MATERIALS (ASTM). C14O Standard Test Methods for Sampling and Testing Concrete Masonry Units and Related Units. West Conshohocken, Pennsylvania, 2002.

AMERICAN SOCIETY FOR TESTING AND MATERIALS (ASTM). C188-17 Standard Test Method for Density of Hydraulic Cement. American Society for Testing and Materials. West Conshohocken, Pennsylvania, 2017.

AMERICAN SOCIETY FOR TESTING AND MATERIALS (ASTM). C494/ C494M-17 - Standard Specification for Chemical Admixtures for Concrete. West Conshohocken, Pennsylvania, 2017.

AMERICAN SOCIETY FOR TESTING AND MATERIALS (ASTM). C642 Standard test method for density, absorption, and voids in hardened concrete. West Conshohocken, Pennsylvania, 2006

AMERICAN SOCIETY FOR TESTING AND MATERIALS (ASTM). C9O Standard Specification for Load-Bearing Concrete Masonry Units. West Conshohocken, Pennsylvania, 2009
BILODEAU, A.; SIVASUNDARM, V:; PAINTER, K. E.; MALHOLTRA, V. M. Durability of concrete incorporating high volumes of fly ash from sources in U.S. ACl Materials Journal, v. 91, v. 1, p. 3-12, 1994. https://doi.org/10.14359/4411

CHEERAROT, R.; JATURAPITAKKUL, C. A study of disposed fly ash from landfill to replace Portland cement. Waste Management, v. 24, n. 7, p. 701 709, 2004. https://doi.org/10.1016/j.wasman.2004.02.003

CHINDAPRASIRT, P.; PIMRAKSA, K. A study of fly ash-lime granule unfired brick. Powder Technology, v. 182, n. 1, p. 33-41, 2008. https://doi.org/10.1016/j. powtec.2007.05.001

CHOU, M. I. M.; PATEL, V.; LAIRD, C. J.; HO, K. K. Chemical and engineering properties of fired bricks containing 50 weight percent of class F fly ash. Energy Sources, v. 23, n. 7. p. 665-673, 2001. https://doi. org/10.1080/00908310119850

CICEK, T.; TANRIVERDI, M. Lime based steam autoclaved fly ash bricks. Construction and Building Materials, v. 21, n. 6, p. 1295-1300, 2007. https:// doi.org/10.1016/j.conbuildmat.2006.01.005

COMITÉ EUROPEU DE NORMALIZAÇÃO (CEN). EN 771-1:2011+A1:2015 - Specification for Masonry Units - Part 1: Clay Masonry Units. European Committee for Standardization, 2015

DEUTSCHES INSTITUT FÜR NORMUNG (DIN). EN ISO 29581-2 - Methods of Testing Cement Chemical Analysis of Cement - Part 2: Analysis by X-Ray Fluorescence. DIN Standards, 2007.

EUROPÄISCHE NORM (EN). 772-11 - Methods of test for masonry units - Part 11: Determination of water absorption of aggregate concrete, manufactured stone and natural stone masonry units due to capillary action and the initial rate of water absorption of clay masonry units. European Standards, 2011. 
GARCIA-UBAQUE, C. A.; MORENO-PIRAJÁN, J. C.; GIRALDO-GUTIERREZ, L.; SAPAG, K. Stabilization/solidification of ashes in clays used in the manufacturing of ceramic bricks, sabilization/solidification of ashes in clays used in the manufacturing of ceramic bricks. Waste Management \& Research, v. 25, n. 4, p. 352-362, 2007. https://doi.org/10.1177/0734242X07077820

GUPTA, V:; PATHAK, D. K.; SIDDIQUE, S.; KUMAR, R.; CHAUDHARY, S. Study on the mineral phase characteristics of various Indian biomass and coal fly ash for its use in masonry construction products. Construction and Building Materials, v. 235, 2020. https://doi.org/10.1016/j.conbuildmat.2019.117413

HUSILLOS RODRIGUEZ, N.; MARTINEZ-RAMIREZ, S.; BLANCO-VARELA, M. T.; DONATELLO, S.; GUILLEM, M.; PUIG, J.; FOS, C.; LARROTCHA, E.; FLORES, $J$. The effect of using thermally dried sewage sludge as an alternative fuel on Portland cement clinker production. Journal of Cleaner Production, v. 52, n. 1, p. 94-102, 2013. https://doi.org/10.1016/J.JCLEPRO.2013.02.026

KUMAR, S. A perspective study on fly ash-lime-gypsum bricks and hollow blocks for low cost housing development. Construction and Building Materials, v. 16, n. 8, p. 519-525, 2002. https://doi.org/10.1016/S09500618(O2)00034-X

LINGLING, X.; WEI, G.; TAO, W.; NANRU, Y. Study on fired bricks with replacing clay by fly ash in high volume ratio. Construction and Building Materials, v. 19, n. 3. p. 243-247. https://doi.org/10.1016/j.conbuildmat.2004.05.017

MCLELLAN, B. C.; WILLIAMS, R. P.; LAY, J.; VAN RIESSEN, A.; CORDER, G. $D$. Costs and carbon emissions for geopolymer pastes in comparison to ordinary portland cement. Journal of Cleaner Production, v. 19, n. 9-10, p. 1080-1090, 2011. https://doi.org/10.1016/j.jclepro.2011.02.010

MOHAMMED, T. U.; HAMADA, H.; YAMAJI, T. Performance of seawatermixed concrete in the tidal environment. Cement and Concrete Research, v. 34, n. 4, p. 593-601, 2004. https://doi.org/10.1016/j.cemconres.2003.09.020
MURMU, A. L.; PATEL, A. Towards sustainable bricks production: An overview. Construction and Building Materials, v. 165, p. 112-125, 2018. https:// doi.org/10.1016/j.conbuildmat.2018.01.038

OZDEMIR, A. Sorptivity potentials of some construction materials Engineering Geology, v. 26, n. 1, p. 19-32, 2002.

PAHRORAJI, M. E. H. M.; SAMAN, H. M.; RAHMAT, M. N.; KAMARUDDIN, K. Properties of coal ash foamed brick stabilised with hydrated lime-activated ground granulated blastfurnace slag. Construction and Building Materials, v. 235, 2020. https://doi.org/10.1016/j.conbuildmat.2019.117568

TOKYAY, M.; CETIN, B. The strength and water absorption properties of fly ash - lime bricks compacted and steam cured. IMO Technical Journal, v. 2 p. 385-394, 1991.

TURGUT, P. Masonry composite material made of limestone powder and fly ash. Powder Technology, v. 204, n. 1, p. 42-47, 2010. https://doi.org/10.1016/j. powtec.2010.07.004

TURGUT, P. Manufacturing of building bricks without Portland cement Journal of Cleaner Production, v. 37, p. 361-367, 2012. https://doi.org/10.1016/j. jclepro.2012.07.047

TURGUT, P. Fly ash block containing limestone and glass powder wastes. KSCE Journal of Civil Engineering, v. 17, n. 6, p. 1425-1431, 2013. https://doi. org/10.1007/s12205-013-0280-6

VIALLIS-TERRISSE, H.; NONAT, A.; PETIT, J. C. Zeta-potential study of calcium silicate hydrates interacting with alkaline cations. Journal of Colloid and Interface Science, v. 244, n. 1, p. 58-65, 2001. https://doi.org/10.1006/jcis.2001.7897

ZHANG, L. Production of bricks from waste materials-A review. Construction and building materials, v. 47, p. 643-655, 2013. https://doi.org/10.1016/j. conbuildmat.2013.05.043 